\title{
BABAM1 Gene
}

National Cancer Institute

\section{Source}

National Cancer Institute. BABAM1 Gene. NCI Thesaurus. Code C124112.

This gene is involved in the formation of the BRISC and BRCA1-A complex. 